\title{
Planned Activity Name
}

National Cancer Institute

\section{Source}

National Cancer Institute. Planned Activity Name. NCI Thesaurus. Code C93997.

A non-unique textual identifier for the planned activity. 